NASA/TM-2004-212901

\title{
Preliminary Analysis of X-Band and Ka-Band Radar for Use in the Detection of Icing Conditions Aloft
}

Andrew L. Reehorst

Glenn Research Center, Cleveland, Ohio

George G. Koenig

U.S. Army Cold Regions Research and Engineering Laboratory, Hanover, New Hampshire 
Since its founding, NASA has been dedicated to the advancement of aeronautics and space science. The NASA Scientific and Technical Information (STI) Program Office plays a key part in helping NASA maintain this important role.

The NASA STI Program Office is operated by Langley Research Center, the Lead Center for NASA's scientific and technical information. The NASA STI Program Office provides access to the NASA STI Database, the largest collection of aeronautical and space science STI in the world. The Program Office is also NASA's institutional mechanism for disseminating the results of its research and development activities. These results are published by NASA in the NASA STI Report Series, which includes the following report types:

- TECHNICAL PUBLICATION. Reports of completed research or a major significant phase of research that present the results of NASA programs and include extensive data or theoretical analysis. Includes compilations of significant scientific and technical data and information deemed to be of continuing reference value. NASA's counterpart of peerreviewed formal professional papers but has less stringent limitations on manuscript length and extent of graphic presentations.

- TECHNICAL MEMORANDUM. Scientific and technical findings that are preliminary or of specialized interest, e.g., quick release reports, working papers, and bibliographies that contain minimal annotation. Does not contain extensive analysis.

- CONTRACTOR REPORT. Scientific and technical findings by NASA-sponsored contractors and grantees.
- CONFERENCE PUBLICATION. Collected papers from scientific and technical conferences, symposia, seminars, or other meetings sponsored or cosponsored by NASA.

- SPECIAL PUBLICATION. Scientific, technical, or historical information from NASA programs, projects, and missions, often concerned with subjects having substantial public interest.

- TECHNICAL TRANSLATION. Englishlanguage translations of foreign scientific and technical material pertinent to NASA's mission.

Specialized services that complement the STI Program Office's diverse offerings include creating custom thesauri, building customized databases, organizing and publishing research results ... even providing videos.

For more information about the NASA STI Program Office, see the following:

- Access the NASA STI Program Home Page at http://www.sti.nasa.gov

- E-mail your question via the Internet to help@sti.nasa.gov

- Fax your question to the NASA Access Help Desk at 301-621-0134

- Telephone the NASA Access Help Desk at 301-621-0390

- Write to:

NASA Access Help Desk

NASA Center for AeroSpace Information 7121 Standard Drive

Hanover, MD 21076 
NASA/TM-2004-212901

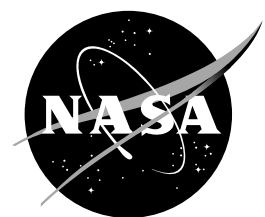

\title{
Preliminary Analysis of X-Band and Ka-Band Radar for Use in the Detection of Icing Conditions Aloft
}

\author{
Andrew L. Reehorst \\ Glenn Research Center, Cleveland, Ohio \\ George G. Koenig \\ U.S. Army Cold Regions Research and Engineering Laboratory, Hanover, New Hampshire
}

Prepared for the

42nd Aerospace Sciences Meeting and Exhibit

sponsored by the American Institute of Aeronautics and Astronautics

Reno, Nevada, January 5-8, 2004

National Aeronautics and

Space Administration

Glenn Research Center 


\section{Acknowledgments}

The authors would like to thank Jothiram Vivekanandan of NCAR for his invaluable help in reviewing the fundamental physics and numerical formulations used throughout this paper.

Available from

NASA Center for Aerospace Information 7121 Standard Drive

Hanover, MD 21076
National Technical Information Service 5285 Port Royal Road Springfield, VA 22100

Available electronically at http:/ /gltrs.grc.nasa.gov 


\title{
PRELIMINARY ANALYSIS OF X-BAND AND KA-BAND RADAR FOR USE IN THE DETECTION OF ICING CONDITIONS ALOFT
}

\author{
Andrew L. Reehorst \\ National Aeronautics and Space Administration \\ Glenn Research Center \\ Cleveland, Ohio \\ George G. Koenig \\ Cold Regions Research \& Engineering Laboratory \\ Hanover, New Hampshire
}

\begin{abstract}
NASA and the U.S. Army Cold Regions Research and Engineering Laboratory (CRREL) have an on-going activity to develop remote sensing technologies for the detection and measurement of icing conditions aloft. Radar has been identified as a strong tool for this work. However, since the remote detection of icing conditions with the intent to identify areas of icing hazard is a new and evolving capability, there are no set requirements for radar sensitivity. This work is an initial attempt to quantify, through analysis, the sensitivity requirements for an icing remote sensing radar.

The primary radar of interest for cloud measurements is Ka-band, however, since NASA is currently using an $\mathrm{X}$-band unit, this frequency is also examined. Several aspects of radar signal analysis were examined. Cloud reflectivity was calculated for several forms of cloud using two different techniques. The Air Force Geophysical Laboratory (AFGL) cloud models, with different drop spectra represented by a modified gamma distribution, were utilized to examine several categories of cloud formation. Also a fundamental methods approach was used to allow manipulation of the cloud droplet size spectra. And an analytical icing radar simulator was developed to examine the complete radar system response to a configurable multi-layer cloud environment.
\end{abstract}

Also discussed is the NASA vertical pointing X-band radar. The radar and its data system are described, and several summer weather events are reviewed.

\section{INTRODUCTION}

Icing is a continuing threat to aircraft flying over much of the globe. While means have been developed over the years to protect aircraft from icing, there continue to be accidents caused by airframe icing. Analyses of these accidents indicate that in many cases the flight crew is unaware of the severity or even presence of these conditions. Flight safety could be enhanced if there were a means to notify flight crews of icing conditions before it was encountered. However, there is currently no way to remotely determine the presence of icing conditions aloft. Current icing condition warnings are based upon prior pilot encounter reports or weather analysis. As part of the NASA Aviation Safety Program, NASA Glenn's Icing Branch has been working with the U.S. Army Cold Regions Research and Engineering Laboratory (CRREL) in the development of technologies capable of remotely detecting icing conditions. The technologies that NASA has examined ${ }^{1}$ include radiometry, lidar, and radar. Of these technologies, radar has the greatest capability to accurately locate specific meteorological conditions, and therefore will almost assuredly be a part of any future system that can accurately define and locate icing conditions.

\section{CLOUD DROP SIZE DISTRIBUTION MODELS}

The performance of the radar system depends, in part, on the cloud radar reflectivity factor $\mathrm{z}$ defined as

$$
z=\sum N_{i} D_{i}{ }^{6}=64 \sum N_{i} r_{i}^{6}
$$

where $N_{i}$ is the number of drops with diameter $D_{i}$. The radar reflectivity factor used in the radar simulation is calculated using the Air Force Research Laboratory cloud models based on the work of Silverman and Sprague. $^{2}$ The general drop size distribution is cast in terms of a gamma distribution.

$$
n(r)=a r^{\alpha} \exp (-b r)
$$

The shape parameters ( $a, \alpha$, and $b$ ), total number of particles per unit volume $\left(N_{o}\right)$, and liquid water content for the different cloud types based on Silverman's compilation is presented in table 1 . 
Table 1.-Cloud model drop size distribution shape parameters, drop concentrations, and liquid water contents.

\begin{tabular}{|l|c|c|c|c|c|}
\hline Cloud Type & $\alpha$ & $b$ & $N_{o}\left(\mathrm{~cm}^{-3}\right)$ & $a$ & $\mathrm{M}\left(\mathrm{g} / \mathrm{m}^{3}\right)$ \\
\hline Cumulus & 3 & 0.5 & 250 & 2.604 & 1.00 \\
\hline Altostratus & 5 & 1.11 & 400 & 6.268 & 0.41 \\
\hline Stratocumulus & 5 & 0.8 & 200 & 0.4369 & 0.55 \\
\hline Nimbostratus & 1 & 0.333 & 100 & 11.089 & 0.27 \\
\hline Stratus & 3 & 0.667 & 250 & 8.247 & 0.42 \\
\hline Stratus & 2 & 0.6 & 250 & 27.00 & 0.29 \\
\hline Stratus-Stratocumulus & 2 & 0.75 & 250 & 52.734 & 0.15 \\
\hline Stratocumulus & 2 & 0.5 & 150 & 9.375 & 0.30 \\
\hline Nimbostratus & 2 & 0.425 & 200 & 7.676 & 0.65 \\
\hline Cumulus-Cumulus Congestus & 2 & 0.328 & 80 & 1.4115 & 0.57 \\
\hline
\end{tabular}

To compute the concentration as a function of drop radius a normalized distribution was computed for each cloud type using

$$
p(r)=\frac{a r^{\alpha} \exp (-b r)}{\int_{r=0}^{r=50} a r^{\alpha} \exp (-b r) d r}
$$

The drop concentration as a function of radius used to compute the cloud radar reflectivity was obtained from

$$
N(r)=N_{o} * P(r)
$$

The cloud drop distribution, $N(r)$, can be used to obtain the Liquid Water Content (LWC) and the Median Volume Diameter (MVD).

\section{FUNDAMENTAL METHODS APPROACH OF EXAMINING RADAR SENSITIVITY TO ICING CONDITIONS}

The radar simulator that will be discussed in detail later in this report is based upon the fundamental equations ${ }^{3}$ of radar design. Of these equations, the most important are the definition of radar reflectivity factor,

$$
z=\sum N_{i} D_{i}^{6}
$$

and the radar equation,

$$
z=c_{3} p_{r} r^{2}
$$

where,

$p_{r} \quad$ received power from target $(\mathrm{mW})$

$r \quad$ range to target $(\mathrm{km})$

$c_{3} \quad$ radar constant such that:

$$
c_{3}=\frac{1024 \ln (2) \lambda^{2}}{\pi p_{t} g^{2} \vartheta \phi|\kappa|^{2}}
$$

and,

$\lambda$ wavelength

$p_{t} \quad$ peak transmitter power $(\mathrm{mW})$

$g$ antenna gain

$\theta \quad$ horizontal beamwidth (radians)

$\phi \quad$ vertical beamwidth (radians)

$|\kappa|^{2} \quad$ dielectric constant term

Due to the huge range in values for reflectivity, these terms are typically manipulated in logarithmic form, and the radar equation becomes:

$$
Z=10 \log _{10}(z)=P_{r}+20 \log _{10}(r)+C_{3}
$$

where,

$$
\begin{aligned}
& P_{r}=10 \log _{10}\left(p_{r}\right) \\
& C_{3}=10 \log _{10}\left(c_{3}\right)
\end{aligned}
$$

The radars being examined were the product of a NASA small business contract. The goal of this contract was to develop a dual-frequency (X-band and Ka-band) radar system that was capable of remotely detecting and measuring cloud liquid water. After delivery to NASA, it became apparent that the system was not accurately detecting and measuring liquid clouds.

X-band system description:

Antenna diameter: 24 inches

Frequency: $9.35 \mathrm{Ghz}$

Peak Power: $10 \mathrm{~kW}$

Pulse Length: $1 \mu \mathrm{s}$

Minimum detectable signal: $-123 \mathrm{dBm}$

Radar constant: $87.76 \mathrm{~dB}$ 
Ka-band system description:

Antenna diameter: 6 inches

Frequency: $33.4 \mathrm{Ghz}$

Peak Power: $30 \mathrm{~W}$

Pulse Length: $1 \mu \mathrm{s}$

Minimum detectable signal: $-123 \mathrm{dBm}$

Radar constant: $101.93 \mathrm{~dB}$

Based upon the specifications of the two systems, their sensitivity to detect a low intensity icing condition (LWC $=0.1 \mathrm{~g} / \mathrm{m}^{3}$ and MVD $=15 \mu \mathrm{m}$ ) was calculated. This LWC and MVD pair was selected to define the minimal icing condition that would need to be detected. Conditions with less moisture or with smaller droplets are assumed to be of minimal threat to aircraft on approach to landing. While these conditions can cause a flight hazard with extended exposure, for the purposes of remote sensing, they are seen to be an adequate minimum condition. Using an equation that is described below, the reflectivity for these conditions is calculated to be $-28 \mathrm{dBZ}$. Using the radar equation, the lower detection bound of the radars were calculated from the surface to 25,000 feet. Figure 1 shows the sensitivity of the X-band radar. The calculations indicate that this radar should be able to detect even these very low intensity conditions up to approximately 7,800 feet above ground level (AGL).

Similar calculations based upon the Ka-band radar's specifications (Figure 2) indicate that it is much less sensitive to liquid water clouds. This system would be able to detect the $0.1 \mathrm{~g} / \mathrm{m}^{3}$ and $15 \mu \mathrm{m}$ cloud no higher than approximately $1,500 \mathrm{ft}$ AGL. While these conditions are quite low in intensity, Figure 2 also shows that even a significantly higher reflectivity could not be detected at a much higher altitude.

Due to the apparent limitations of the Ka radar, an attempt was made to examine an improved system. A radar's ability to detect can be increased by either increasing the transmit power, increasing the receiver's sensitivity, or increasing the antenna gain. The only practical improvement to this system would be an increase of antenna gain by replacing the existing antenna with a larger one. The Ka-band radar's sensitivity was recalculated assuming a 24 inch diameter antenna. With this larger antenna, the calculations indicate that the modified radar would be capable of detecting our low intensity icing conditions out to approximately 7,200 ft AGL (Figure 3).

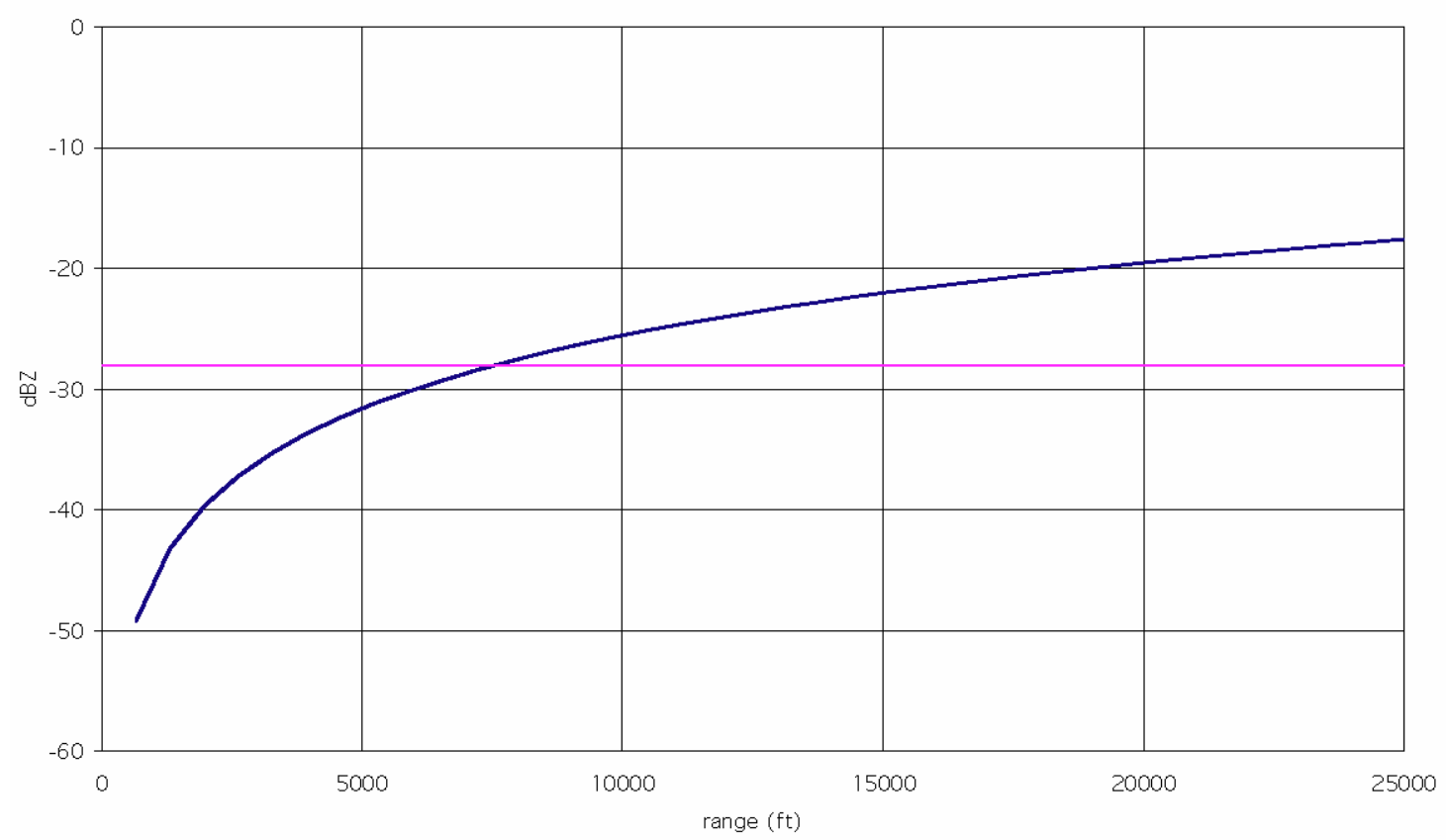

Figure 1.—NASA vertical pointing X-band radar minimum detectable reflectivity. 


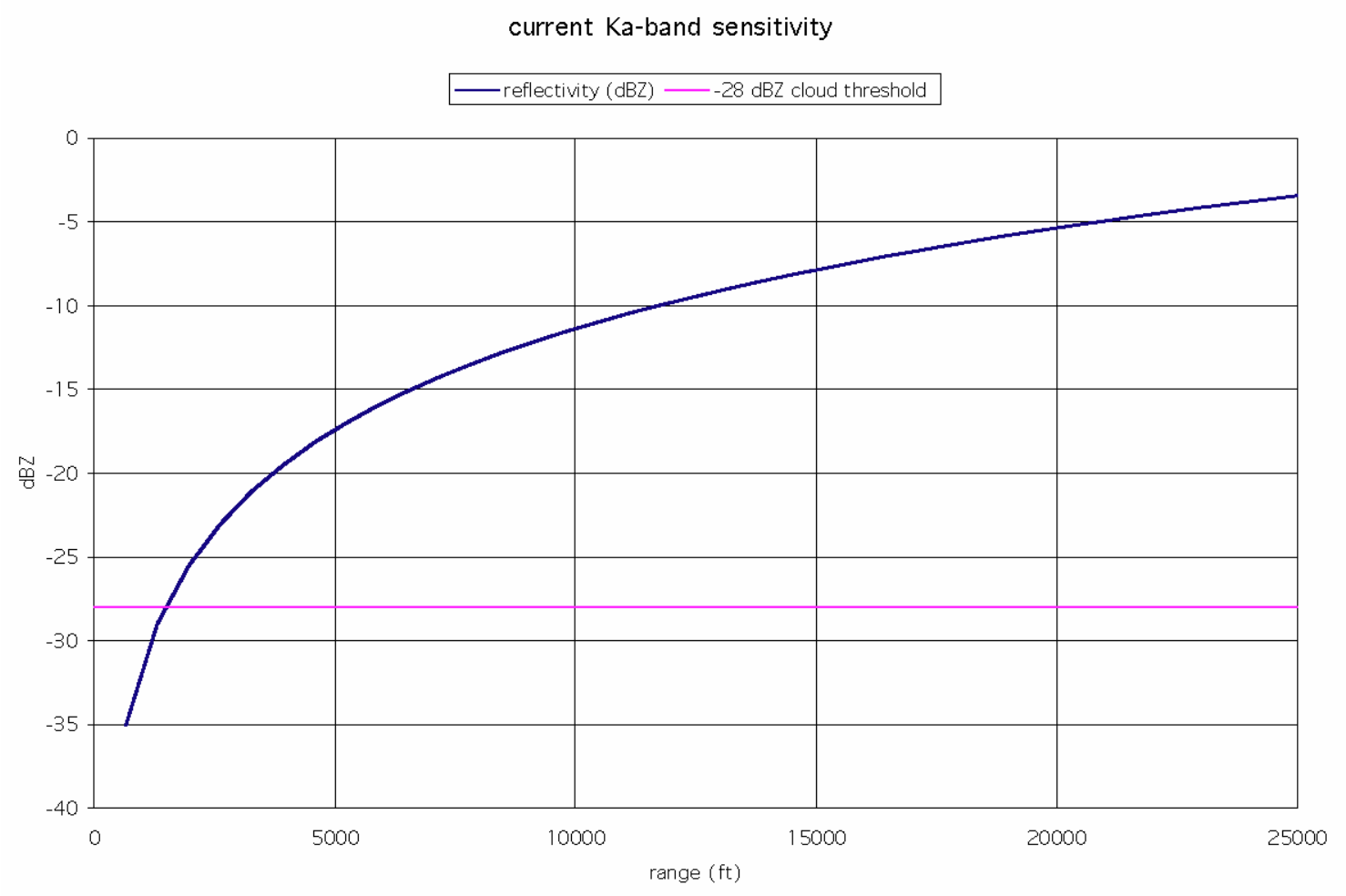

Figure 2.-Existing Ka-band radar (with 6 inch antenna) minimum detectable reflectivity.

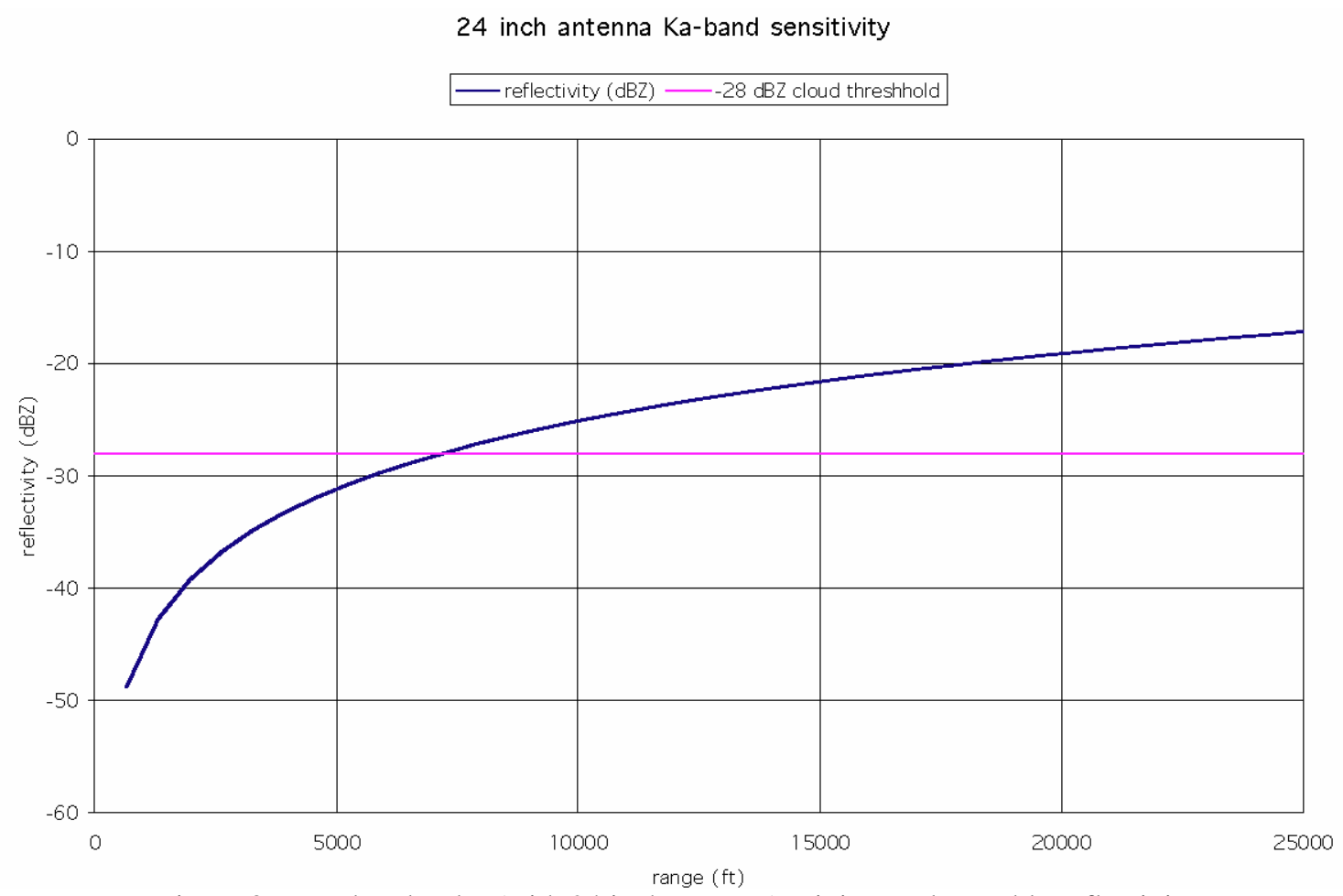

Figure 3.-Ka-band radar (with 24 inch antenna) minimum detectable reflectivity. 


\section{A SIMPLE ANALYTICAL ICING RADAR SIMULATOR}

Besides the sensitivity analysis of the Ka radar with the existing 6 inch antenna and a recommended 24 inch antenna, analysis was also conducted for 36 and 48 inch antenna configurations. As would be expected, the larger the antenna, the better the radar sensitivity. However, based upon the cost of a new antenna and radome and the required modifications required for the installation of both, the most practical configuration for this system was seen to be the 24 inch antenna. Therefore the 24 inch antenna system was the configuration selected for further icing cloud detection simulations.

This simulation models signal contribution from both cloud and rain and corrects for attenuation and receiver noise floor. Inputs to the simulation are rain rate for precipitation below cloud base, and 3 layers of cloud LWC and MVD. With this information and the previously determined radar properties, it is possible to calculate an estimate of the radar's received power and therefore measured reflectivity profiles.

Cloud reflectivity was calculated ${ }^{4}$ with:

$$
Z=10 \log _{10}\left(L W C * M V D^{3} * 4.63 E-06\right)
$$

Rain reflectivity was calculated with the MarshallPalmer formula for stratiform cloud rain: ${ }^{5}$

$$
Z=200 R^{1.6}
$$

where $\mathrm{R}$ is the rainfall rate in $\mathrm{mm} / \mathrm{h}$

Attenuation was modeled by assuming a loss of $1.25 \mathrm{~dB} / \mathrm{km} /\left(\mathrm{g} / \mathrm{m}^{3}\right)$ for supercooled liquid cloud droplets. $^{3}$

The noise floor for this system was calculated based upon a contractor specified Minimum Detectable Signal of $-123 \mathrm{dBm}$.

The first case we will discuss is a simple case of one cloud layer with no rainfall. The cloud was defined as $\mathrm{LWC}=0.2 \mathrm{~g} / \mathrm{m}^{3}$ and $\mathrm{MVD}=30 \mu \mathrm{m}$ between 5,000 and 10,000 feet. Figure 4 shows the resultant received power and Figure 5 shows the corresponding measured reflectivity. This second plot demonstrates good system performance, with the measured reflectivity very close to the actual local cloud reflectivity. While not a significant effect in this case, the attenuation of the signal is visible on both plots, but particularly on the received power plot.

The second case we will examine has a low LWC cloud to help us determine the sensing threshold for the simulated radar. As seen in Figure 6, a cloud with an LWC of $0.1 \mathrm{~g} / \mathrm{m3}$ and MVD of $22 \mathrm{~mm}$ from 5,000 to 10,000 feet is just marginally detectable at the upper range. If the LWC or MVD were lower than this, the upper parts of the cloud would not be detectable.

\section{4" Ka antenna received power}

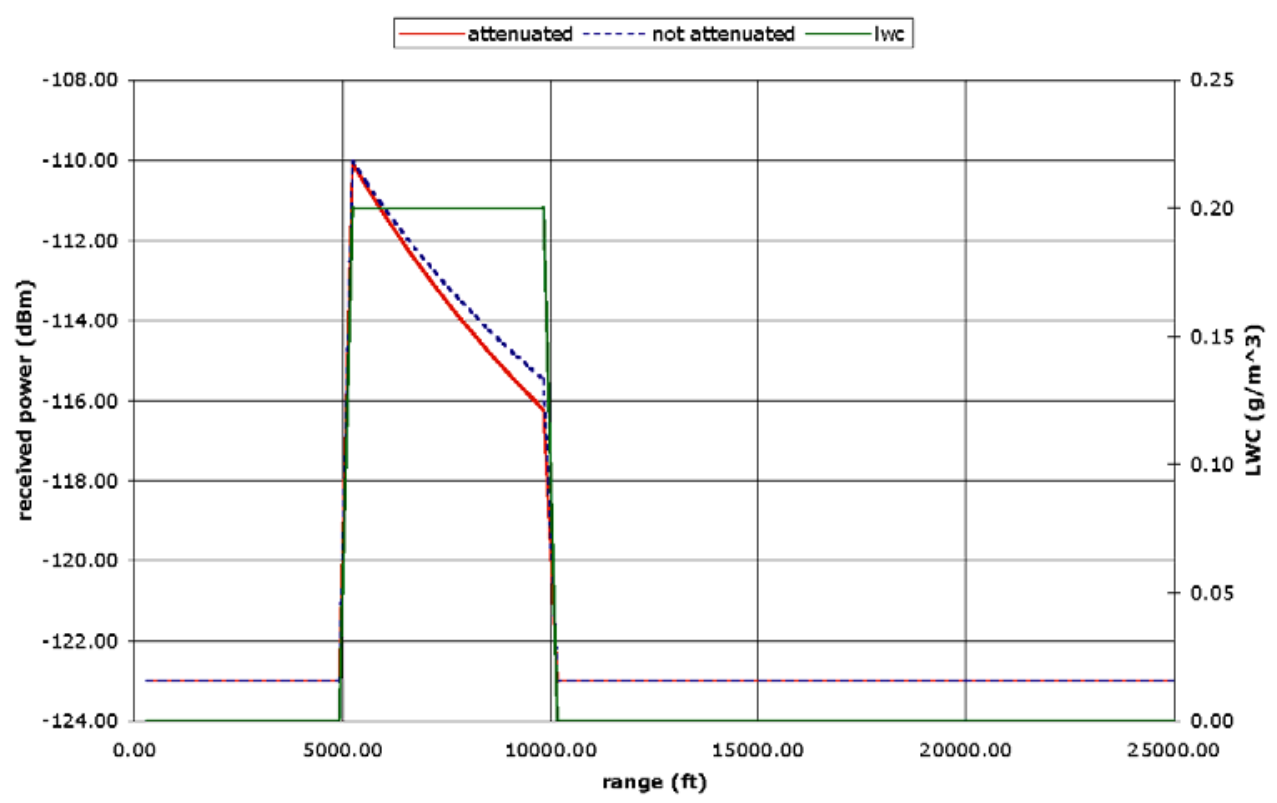

Figure 4.--Received power plot from simulation of existing Ka radar with 24 inch antenna with cloud from 5,000 to 10,000 feet with $\mathrm{LWC}=0.2 \mathrm{~g} / \mathrm{m}^{3}$ and $\mathrm{MVD}=30 \mu \mathrm{m}$. 
24" antenna Ka measured reflectivity

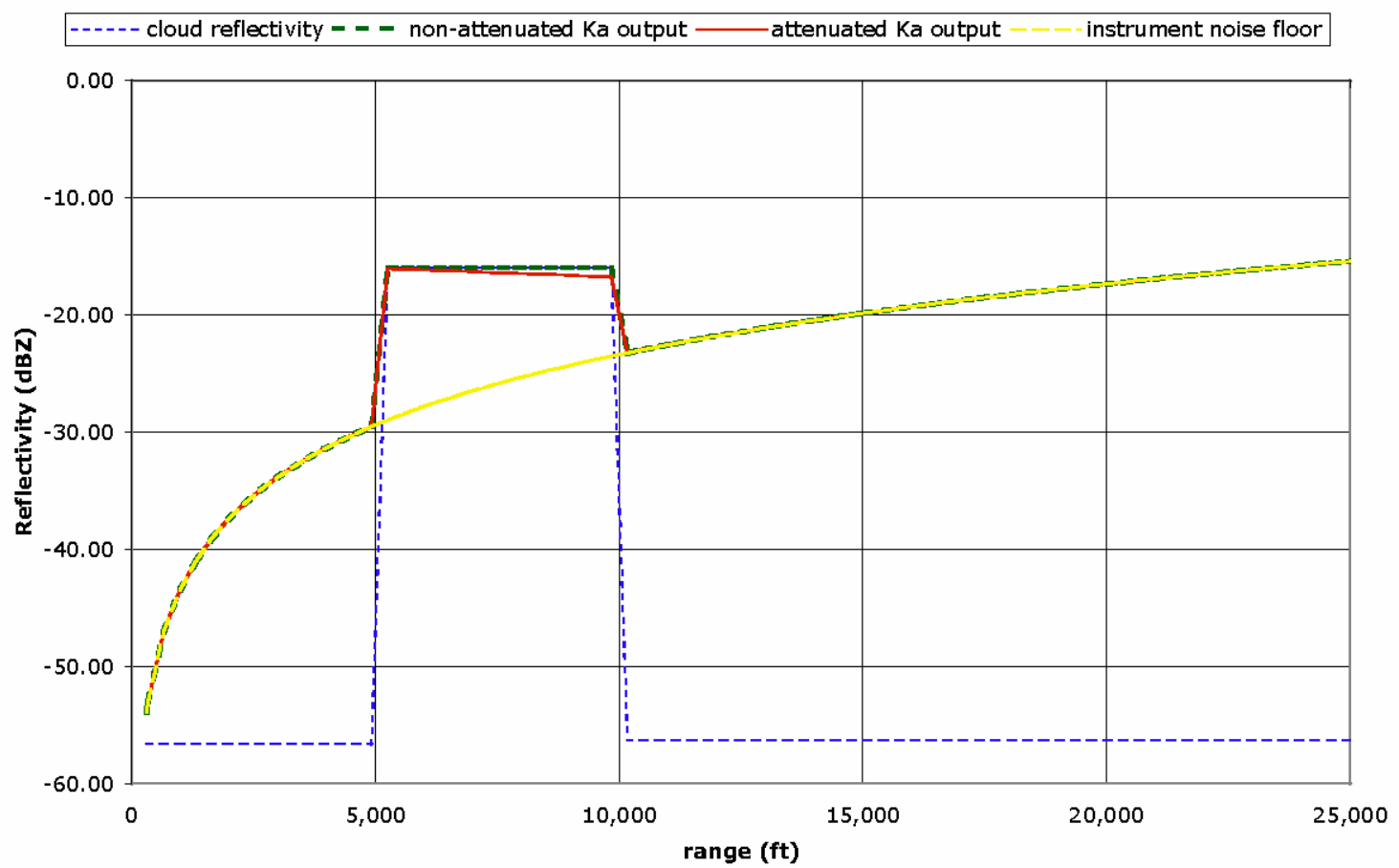

Figure 5.- Measured reflectivity plot from simulation of existing Ka radar with 24 inch antenna with cloud from 5,000 to 10,000 feet with $\mathrm{LWC}=0.2 \mathrm{~g} / \mathrm{m}^{3}$ and $\mathrm{MVD}=30 \mu \mathrm{m}$.

24" antenna Ka measured reflectivity

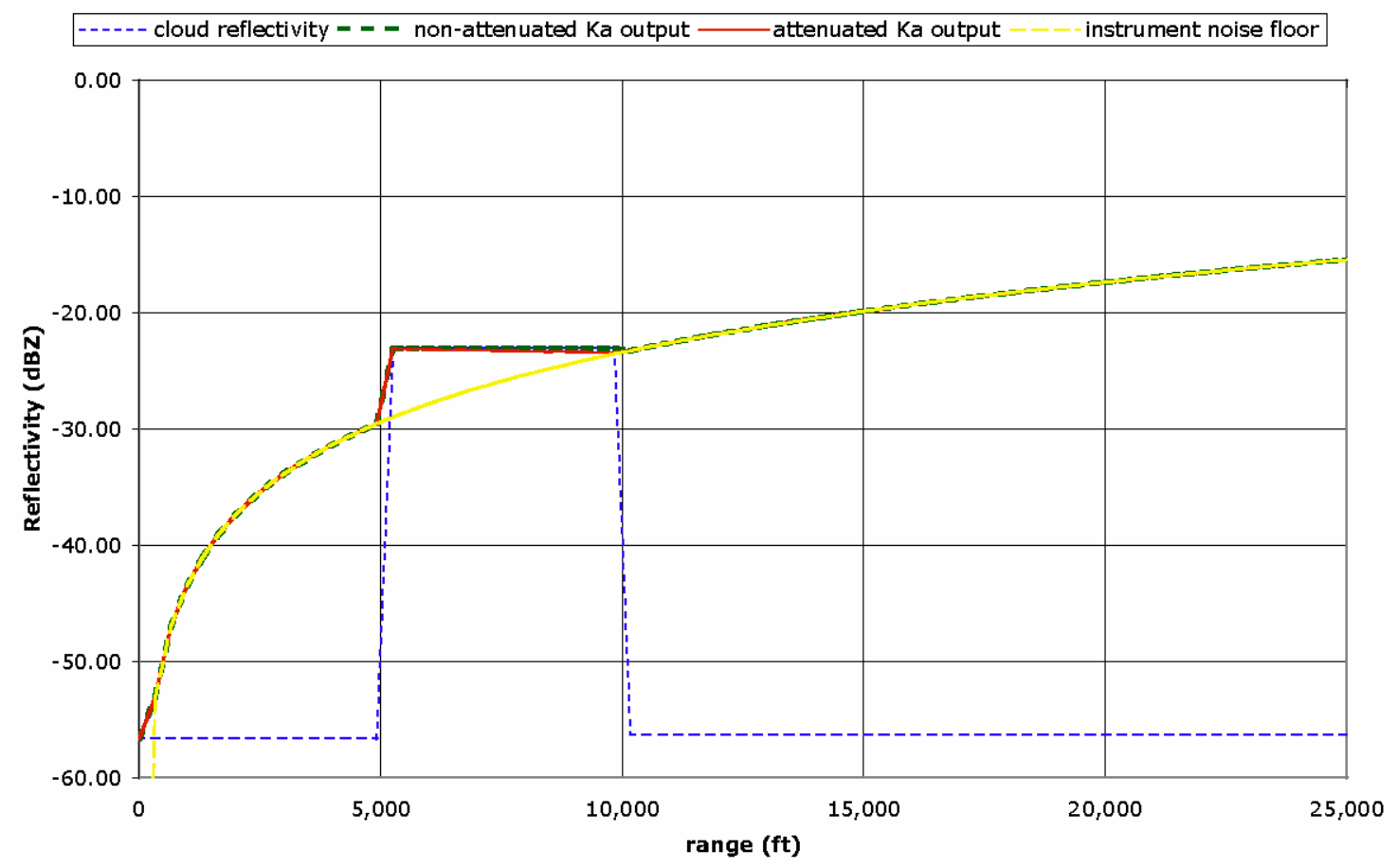

Figure 6.-Measured reflectivity plot from simulation of existing Ka radar with 24 inch antenna with cloud from 5,000 to 10,000 feet with $\mathrm{LWC}=0.10 \mathrm{~g} / \mathrm{m}^{3}$ and MVD=22 $\mu \mathrm{m}$. 
The final case to be examined is a more complicated situation. This case includes multiple cloud layers and rain below the lowest cloud base. For this case the environment is defined as having light rain $(2.54 \mathrm{~mm} / \mathrm{hr})$ from the ground to 5,000 feet, cloud from 5,000 to 10,000 feet with $\mathrm{LWC}=0.30 \mathrm{~g} / \mathrm{m}^{3}$ and $\mathrm{MVD}=30 \mu \mathrm{m}$, cloud from 10,000 to 15,000 feet with $\mathrm{LWC}=0.25 \mathrm{~g} / \mathrm{m}^{3}$ and $\mathrm{MVD}=20 \mu \mathrm{m}$, and cloud from 15,000 to 25,000 feet with $\mathrm{LWC}=0.50 \mathrm{~g} / \mathrm{m}^{3}$ and $\mathrm{MVD}=30 \mu \mathrm{m}$

This case demonstrates the effect of signal attenuation caused by liquid water. As seen in Figure 7, the radar would not detect the entire middle cloud layer and the top third of the upper cloud layer. This is despite the fact that the cloud at this altitude has a reflectivity above the radar's detection threshold. This case is a good example to explain why any radar used to define cloud boundaries for icing condition detection must be specified to take liquid water attenuation into account. Any cloud radar will have range limitations in cloud detectability in an attenuating atmosphere. The combination of the upper range where cloud boundary must be detected and realistic lower altitude liquid levels must be taken into account in order to adequately specify the sensitivity of a radar to be used for cloud detection.

\section{$\underline{\text { Recommendations for Icing Radar Requirements }}$}

As discussed earlier, based upon the analytical simulation of an icing condition remote sensing radar, a sensitivity of $-28 \mathrm{dBZ}$ is required to sense the presence of a cloud with an LWC of $0.1 \mathrm{~g} / \mathrm{m}^{3}$ and an MVD of $15 \mu \mathrm{m}$. This level of sensitivity is required at the maximum altitude of interest. Initially, this should be at least 10,000 feet, to cover the majority of potential icing events. If rain under the cloud and/or multiple cloud layers are also assumed be present, then the radar must have additional sensitivity to account for liquid water attenuation. To adequately define the requirements of the radar component of an icing condition remote sensing system, a sufficiently powerful and sensitive radar is required to experimentally confirm the boundaries of detection as defined by analytical methods. Due to the capability limitations caused by the low power transmitter, the existing Ka-band radar is no longer being developed as a key part of the NASA Icing Remote Sensing System. To fulfill the need for a Ka-band sensor, a new radar is being acquired that will provide much greater transmit power, higher receiver sensitivity, and doppler capability. The new system will have at least $30 \mathrm{~kW}$ transmitter peak power, receiver sensitivity of at least $-45 \mathrm{dBZ}$ at 15,000 ft, maximum range of approximately $50,000 \mathrm{ft}$, and doppler velocity resolution of at least 0.5 knots.

Based upon the preliminary specifications of the radar manufacturer, Figures 8 and 9 show the new system's minimum detectable reflectivity and performance in a multi-layer icing environment (similar to that from Figure 7 above, except the top layer can now be reduced to the $0.1 \mathrm{~g} / \mathrm{m}^{3}$ and $15 \mu \mathrm{m}$ minimum icing condition).

24" antenna Ka measured reflectivity

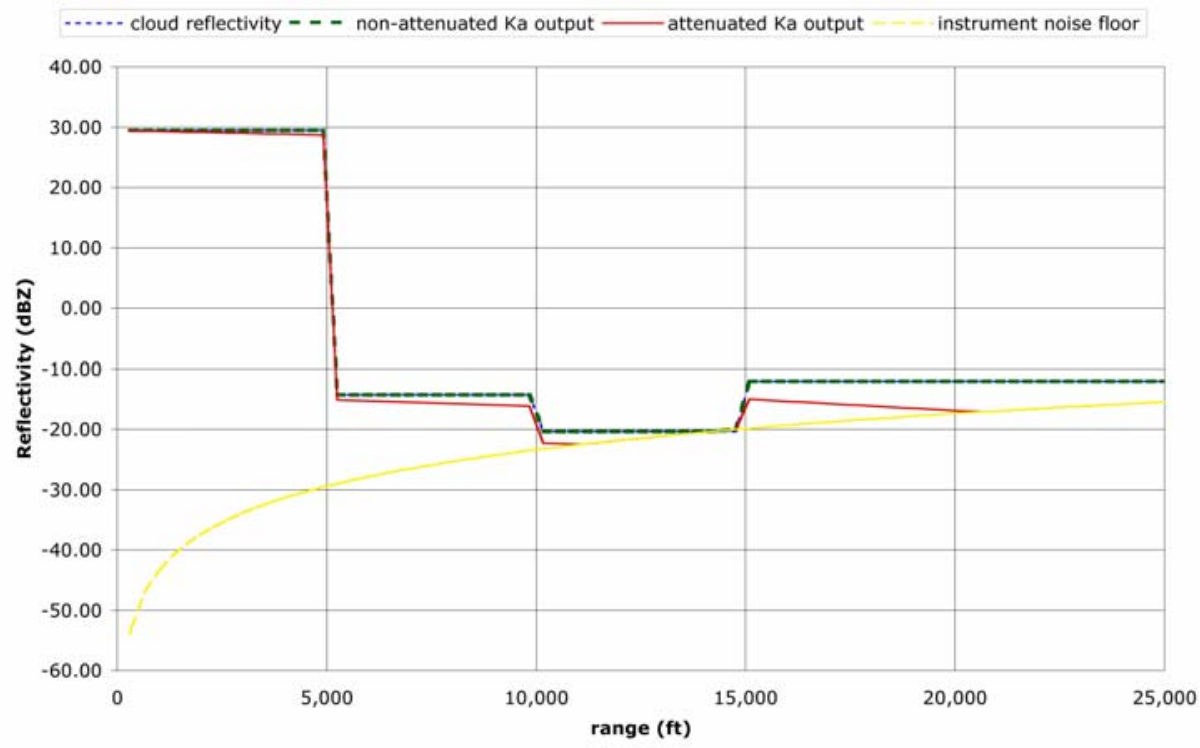

Figure 7.-Measured reflectivity plot from simulation of existing Ka radar with 24 inch antenna with light rain from the ground to 5,000 feet, cloud from 5,000 to 10,000 feet with $\mathrm{LWC}=0.30 \mathrm{~g} / \mathrm{m}^{3}$ and MVD=30 $\mu \mathrm{m}$, cloud from 10,000 to 15,000 feet with $\mathrm{LWC}=0.25 \mathrm{~g} / \mathrm{m}^{3}$ and $\mathrm{MVD}=20 \mu \mathrm{m}$, and cloud from 15,000

to 25,000 feet with $\mathrm{LWC}=0.50 \mathrm{~g} / \mathrm{m}^{3}$ and $\mathrm{MVD}=30 \mu \mathrm{m}$. 


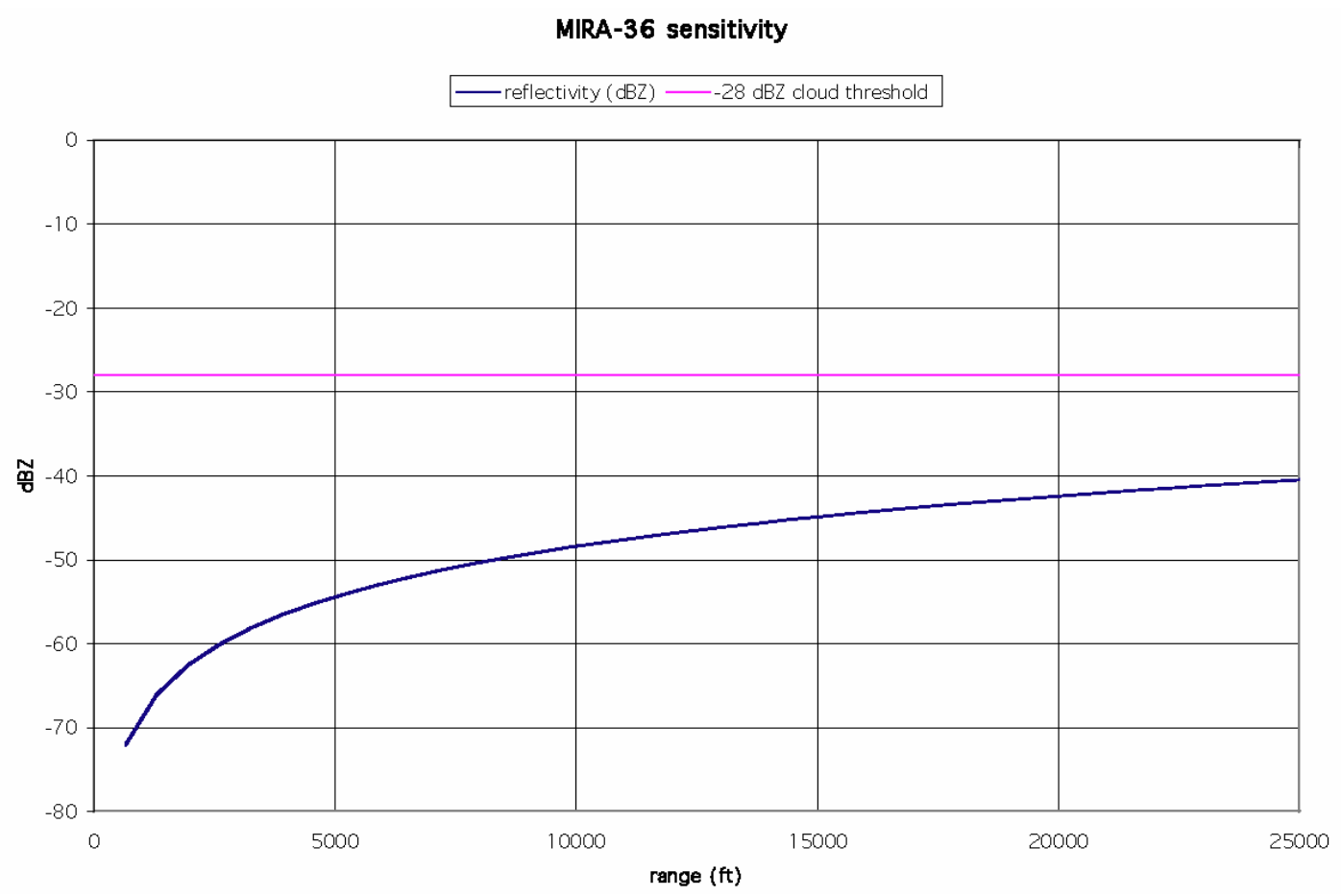

Figure 8.-New Ka-band radar minimum detectable reflectivity.

MIRA-36 measured reflectivity

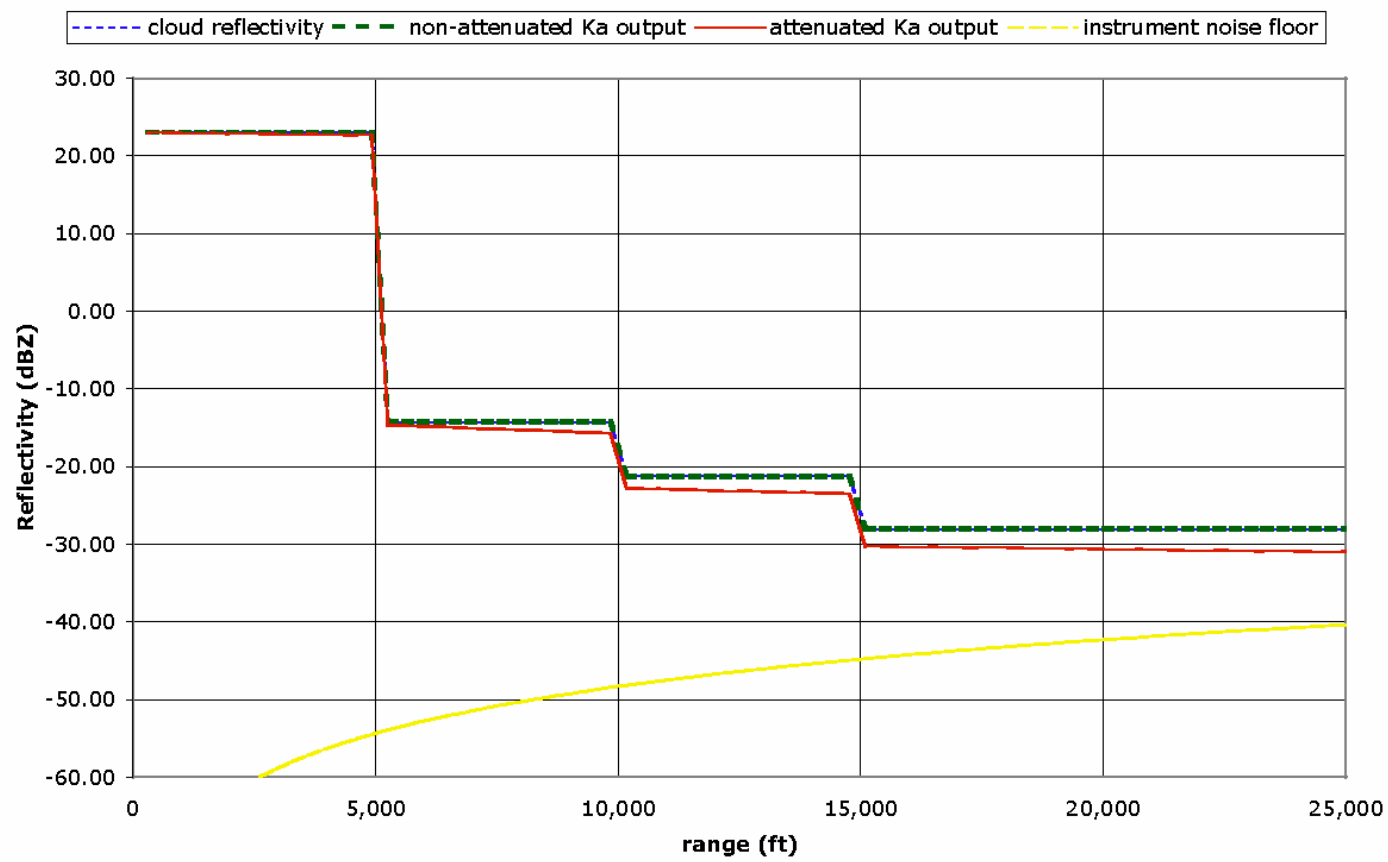

Figure 9.-Measured reflectivity plot from simulation of new Ka-band radar with light rain from the ground to 5,000 feet, cloud from 5,000 to 10,000 feet with $\mathrm{LWC}=0.30 \mathrm{~g} / \mathrm{m}^{3}$ and MVD=30 $\mu \mathrm{m}$, cloud from 10,000 to 15,000 feet with $\mathrm{LWC}=0.25 \mathrm{~g} / \mathrm{m}^{3}$ and $\mathrm{MVD}=20 \mu \mathrm{m}$, and cloud from 15,000 to 25,000 feet with $\mathrm{LWC}=0.10 \mathrm{~g} / \mathrm{m}^{3}$ and $\mathrm{MVD}=15 \mu \mathrm{m}$. 
Description of Current NASA Vertically Pointing $\underline{\text { X-band Radar }}$

Until the new Ka-band radar becomes operational, NASA is operating a vertical pointing X-band radar. The transmitter/receiver is a slightly modified Honeywell WU-870 airborne weather radar unit. ${ }^{6}$ The radar was modified to allow the use of an external data acquisition system and limited operation to its $50 \mathrm{NM}$ /Map mode (1 $\mu$ sec pulses). The standard control unit from Honeywell provides power and basic control to the transmitter/receiver.

Instead of the standard Honeywell display unit, the video signal and trigger signal are output to a data acquisition system. The data acquisition system consists of a Dell 4550 desktop PC running under the Windows XP Operating System, a National Instruments 6110 PCI data acquisition card, and a custom application written in National Instruments LabVIEW programming language.

The LabVIEW program controls the data input to the PCI card, performs signal analysis, displays data to the operator, and stores date/time and range/reflectivity to an ASCII format file. A complimentary post-processing program reads back the data from the file and can plot all or part of the data, and display discrete range/reflectivity data for any sample in the file's dataset. The following figures are screen images from this post-processing program. Figure 10 shows the screen image for a cloud and precipitation event during the summer of 2003. The lower window shows evidence of the bright-band melting layer (region where reflectivity is enhanced by larger ice particles melting as they fall into above freezing air) and wind shear (direction of precipitation is seen to change above and below the bright band layer).

Figure 11 is another screen image for a cloud and precipitation event. On the left side of the lower window we see an intense rain cell that has saturated the receiver and further to the right we see further evidence of a melting layer.

The final figure shows a common effect seen in summer operation of this system in Cleveland, Ohio. Figure 12 shows the return from clear air on a warm August day.

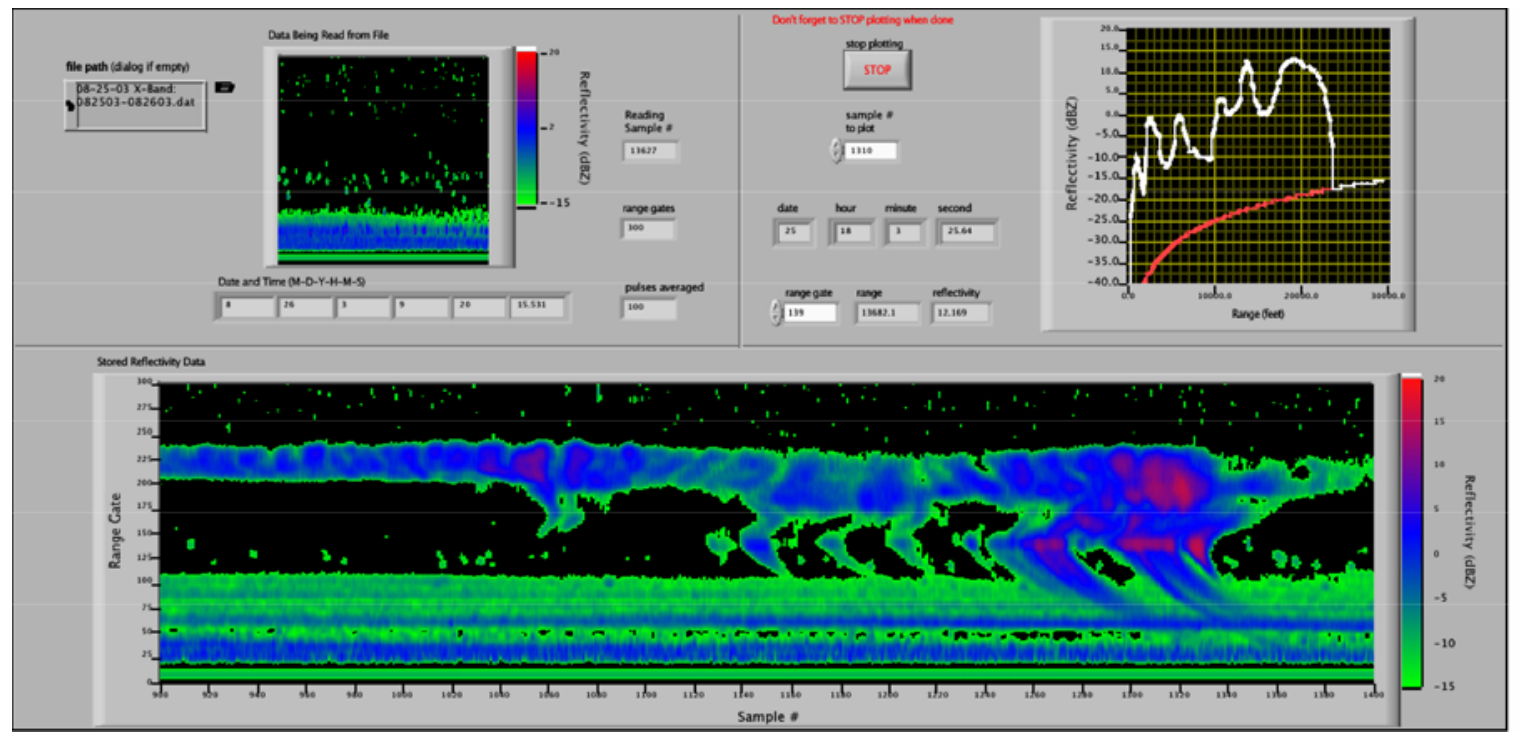

Figure 10.-Graphical output from NASA vertical pointing X-band radar, from cloud and precipitation event from August 26, 2003, showing evidence of bright-band melting layer and wind direction change with altitude. 


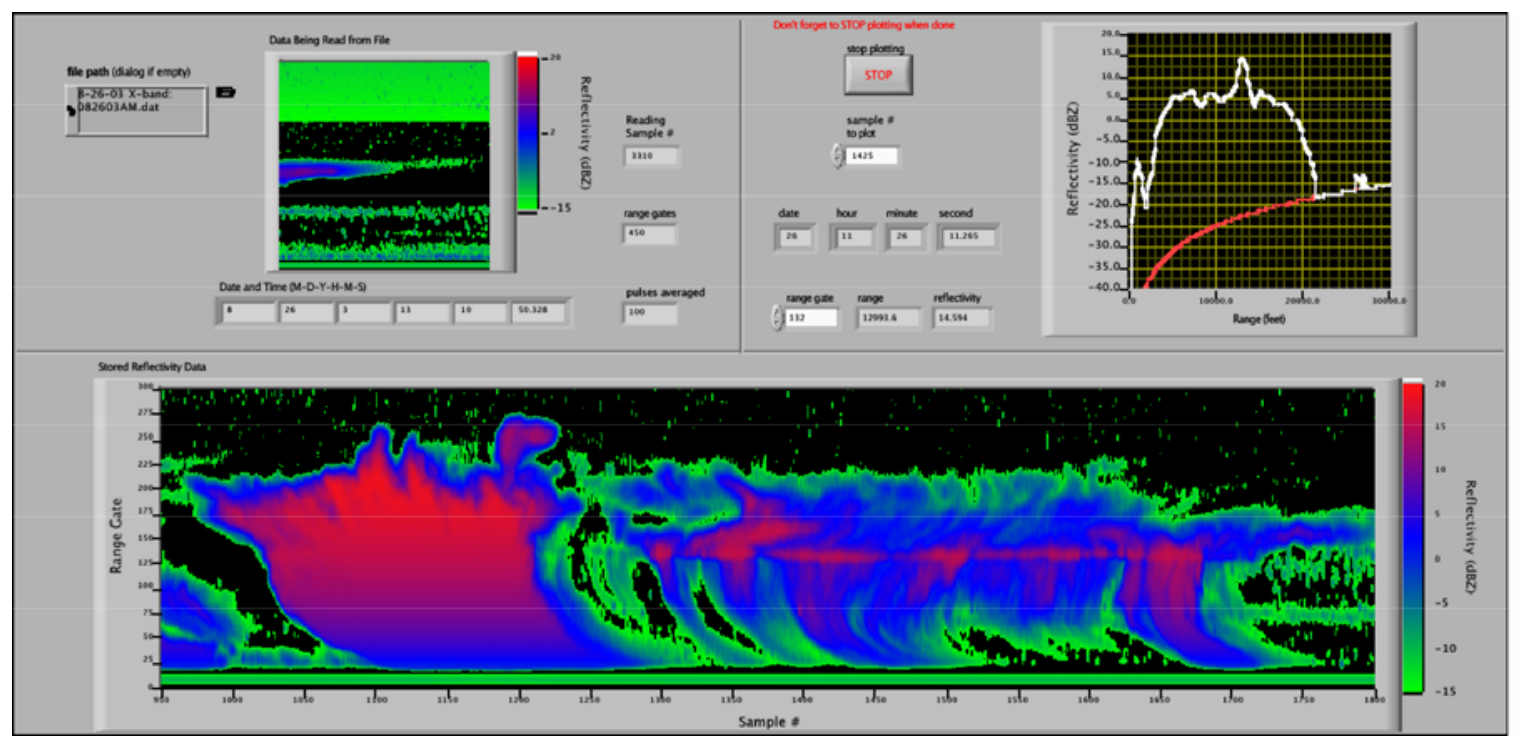

Figure 11.-Graphical output from NASA vertical pointing X-band radar, from another cloud and precipitation event from August 26, 2003, showing more intense rain event and evidence of bright-band melting layer.

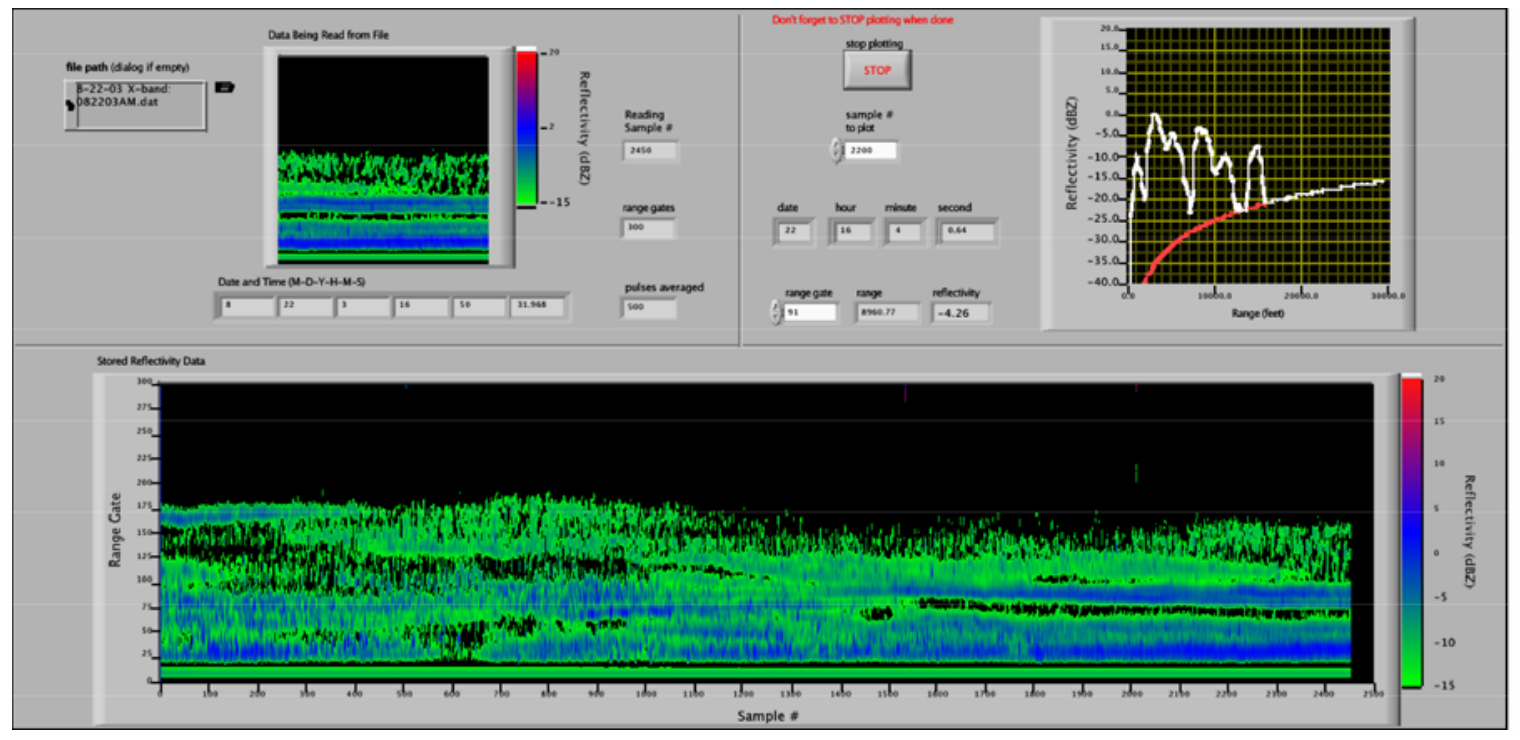

Figure 12.-Graphical output from NASA vertical pointing X-band radar, showing clear air return, likely caused by insects.

There are three forms of clear air return seen in meteorological radars. The first is caused by variations in the refractive index of air caused primarily by humidity and temperature variations. The second form is caused by insects. Insects are almost always present up to the freezing level (except above deserts and oceans), and their radar return is dependent upon their size and water content (dielectric factor). The third cause for clear air return is from wind carried particles (i.e., vegetable debris and seeds) whose size is on the order of a millimeter. The refractive effects are typically not an issue for radars in the X-band. Similarly, the particulate effects are limited to lower altitudes and extremely sensitive radar receivers. ${ }^{7,8}$ Therefore, it must be concluded that insects are the cause for the clear air return detected with the NASA vertical pointing $\mathrm{X}$-band radar. Note the difference between this clear air return in Figure 12 and that seen to the right in Figure 11 (following a rain event). Figure 12 was from a warm, humid day in which a great deal more insects could be expected than following a precipitation event as in Figure 11. The significance of 
this phenomenon is the strength of the measured return during warm weather. With the X-band sensing technology, it is quite difficult to separate the clear air return from that of low-level clouds. Fortunately, for icing condition detection, this should not be an issue for regions with extensively below freezing temperatures. However, to have an automated system capable of operation year-round (for possible higher altitude icing condition detection), this effect will need to be addressed in the future.

\section{REFERENCES}

1. Reehorst, A. and Koenig, G., "Ground-Based Icing Condition Remote Sensing System Definition", NASA/TM-2001-211102, August 2001.

2. Silvman, B.A. and E.D. Sprague, "Airborne Measurements of In Cloud Visibility," Preprints, National Conference on Weather Modification of the Am. Meteorol. Soc., Santa Barbara, California, 6-9 April 1970.
3. Rinehart, R., "Radar for Meteorologists, $3^{\text {rd }}$ edition”, Grand Forks, ND: Rinehart Publications, 1997.

4. Vivekananda, J., Martner, B., Politovich, M., and Zhang, G., "Retrieval of Atmospheric Liquid and Ice Characteristics Using Dual-Wavelength Radar Observations”, IEEE Trans. Geosci. Remote Sensing, vol. 37, no. 5, pp. 2325-2334, 1999.

5. Doviak, R. and Zrnic. D., "Doppler Radar and Weather Observations $2^{\text {nd }}$ edition”, New York: Academic Press, 1993.

6. Savard, J., "WU-870 RADAR for Technology Service Corporation” subcontractor report, Honeywell RADAR Engineering, June 2003.

7. Sauvageot, H., "Radar Meteorology", Boston: Artech House, 1992.

8. Riley. J., "Radar Returns form Insects: Implications for Meteorological Radars”, AMS $29^{\text {th }}$ International Conference on Radar Meteorology, pp. 390-393, July 1999. 
Public reporting burden for this collection of information is estimated to average 1 hour per response, including the time for reviewing instructions, searching existing data sources, gathering and maintaining the data needed, and completing and reviewing the collection of information. Send comments regarding this burden estimate or any other aspect of this collection of information, including suggestions for reducing this burden, to Washington Headquarters Services, Directorate for Information Operations and Reports, 1215 Jefferson Davis Highway, Suite 1204, Arlington, VA 22202-4302, and to the Office of Management and Budget, Paperwork Reduction Project (0704-0188), Washington, DC 20503.

\begin{tabular}{|l|l|l|}
\hline 1. AGENCY USE ONLY (Leave blank) & $\begin{array}{c}\text { 2. REPORT DATE } \\
\text { January } 2004\end{array}$ & $\begin{array}{r}\text { 3. REPORT TYPE AND DATES COVERED } \\
\text { Technical Memorandum }\end{array}$
\end{tabular}

\section{TITLE AND SUBTITLE}

5. FUNDING NUMBERS

Preliminary Analysis of X-Band and Ka-Band Radar for Use in the Detection of Icing Conditions Aloft

6. AUTHOR(S)

Andrew L. Reehorst and George G. Koenig

WBS-22-728-41-05

\section{PERFORMING ORGANIZATION NAME(S) AND ADDRESS(ES)}

National Aeronautics and Space Administration

John H. Glenn Research Center at Lewis Field

Cleveland, Ohio 44135-3191

8. PERFORMING ORGANIZATION REPORT NUMBER

\section{E-14318}

\section{SPONSORING/MONITORING AGENCY NAME(S) AND ADDRESS(ES)}

National Aeronautics and Space Administration

Washington, DC 20546-0001

10. SPONSORING/MONITORING AGENCY REPORT NUMBER

NASA TM-2004-212901

AIAA-2004-0233

\section{SUPPLEMENTARY NOTES}

Prepared for the 42nd Aerospace Sciences Meeting and Exhibit sponsored by the American Institute of Aeronautics and Astronautics, Reno, Nevada, January 5-8, 2004. Andrew L. Reehorst, NASA Glenn Research Center; and George G. Koenig, U.S. Army Cold Regions Research and Engineering Laboratory, Hanover, New Hampshire 03755. Responsible person, Andrew L. Reehorst, organization code 5840, 216-433-3938.

12a. DISTRIBUTION/AVAILABILITY STATEMENT

12b. DISTRIBUTION CODE

Unclassified - Unlimited

Subject Category: 03

Distribution: Nonstandard

Available electronically at http://gltrs.grc.nasa.gov

This publication is available from the NASA Center for AeroSpace Information, 301-621-0390.

13. ABSTRACT (Maximum 200 words)

NASA and the U.S. Army Cold Regions Research and Engineering Laboratory (CRREL) have an on-going activity to develop remote sensing technologies for the detection and measurement of icing conditions aloft. Radar has been identified as a strong tool for this work. However, since the remote detection of icing conditions with the intent to identify areas of icing hazard is a new and evolving capability, there are no set requirements for radar sensitivity. This work is an initial attempt to quantify, through analysis, the sensitivity requirements for an icing remote sensing radar. The primary radar of interest for cloud measurements is Ka-band, however, since NASA is currently using an X-band unit, this frequency is also examined. Several aspects of radar signal analysis were examined. Cloud reflectivity was calculated for several forms of cloud using two different techniques. The Air Force Geophysical Laboratory (AFGL) cloud models, with different drop spectra represented by a modified gamma distribution, were utilized to examine several categories of cloud formation. Also a fundamental methods approach was used to allow manipulation of the cloud droplet size spectra. And an analytical icing radar simulator was developed to examine the complete radar system response to a configurable mulct-layer cloud environment. Also discussed is the NASA vertical pointing X-band radar. The radar and its data system are described, and several summer weather events are reviewed.

14. SUBJECT TERMS

Meteorological radar; Aircraft icing; Aviation meteorology

\begin{tabular}{|c|c|c|}
\hline $\begin{array}{c}\text { 17. SECURITY CLASSIFICATION } \\
\text { OF REPORT } \\
\text { Unclassified }\end{array}$ & $\begin{array}{c}\text { 18. SECURITY CLASSIFICATION } \\
\text { OF THIS PAGE } \\
\text { Unclassified }\end{array}$ & $\begin{array}{c}\text { 19. SECURITY CLASSIFICATION } \\
\text { OF ABSTRACT } \\
\text { Unclassified }\end{array}$ \\
\hline
\end{tabular}

NSN 7540-01-280-5500

15. NUMBER OF PAGES

17

16. PRICE CODE

20. LIMITATION OF ABSTRACT

Standard Form 298 (Rev. 2-89)

Prescribed by ANSI Std. Z39-18 298-102 